overlying unconsolidated deposits. Gravity interpretation shows that the proved density distribution can account quantitatively for the Petrockstow negative gravity anomaly.

A borehole sonic log enabled the determination of average velocity for the strata encountered in the borehole. The distribution of sonic velocities with depth is given in the third column of Table I; unfortunately, no reliable values were recorded between 20 and 400 feet due to signal attenuation. Velosities in the unconsolidated deposits vary between 6,800 feet $\mathrm{s}^{-1}\left(2,070 \mathrm{~m} \mathrm{~s}^{-1}\right)$ and 9,500 feet $\mathrm{s}^{-1}\left(2,900 \mathrm{~m} \mathrm{~s}^{-1}\right)$, and are in contrast with those for the underlying Upper Carboniferous strata which exhibit an average velocity to 12,500 feet $\mathrm{s}^{-1}\left(3,810 \mathrm{~m} \mathrm{~s}^{-1}\right)$.

We thank the Director, Institute of Geological Sciences, for permission to communicate these results.

\title{
REFERENCES
}

Freshney, E. C. \& Fenning, P. J. 1967. The Petrockstow Basin. Proc. Ussher Soc., $1,278-280$.

BotT, M. H. P., DAY, A. A. \& MASSON-SMITH, D. 1958. The geological interpretation of gravity and magnetic surveys in Devon and Cornwall. Phil. Trans. R. Soc., A251, 161-191.

Institute of Geological Sciences,

5 Princes Gate,

LONDON, S.W.7.

P. J. Fenning.

E. C. FRESHNEY.

26th February, 1968.

\section{A MIDDLE WUURM INTERSTADIAL IN SOUTH-WEST WALES}

Sir,-A recent paper by John (Geol. Mag., 104, 630-3) unwittingly illustrates the difficulties of interpretation of derived plant material in glacial deposits; and in view of the greater use currently being made of $\mathbf{C}^{14}$ dating facilities, poses the problem of the acceptability of dates on such material.

$A \mathrm{C}^{14}$ age determination of $33,750 \pm 2,500$ years B.P. was made on derived plant fragments from Cil-maenllwyd in the kamiform Banc-y-Warren sands in South Cardiganshire. On the basis of this $\mathbf{C}^{14}$ determination (and that presented by Brown et al., 1967) John suggests that the sands in which the wood fragments lie were deposited during a "Middle Würm Interstadial", and that the local climate at this period can be inferred from derived pollen contained within the sands.

The pollen analysis presented by John does not support this latter contention, however, but is strikingly different from others of "Middle Würm" age. Many such interstadial sites are now known from both the English Midlands (Shotton, 1967) and from Holland (Van der Hammen et al., 1967) with $\mathbf{C}^{14}$ dates ranging from 29,000 to 43,000 years B.P. The environment indicated by pollen from these sites is one of shrub tundra showing periodic climatic oscillations but no well-marked re-afforestation, Salix and Betula (probably Betula nana) and occasionally Pinus, being the most prominent arboreal pollen. John's pollen analysis, however, indicates a more varied tree flora and much warmer conditions; for example, it reports Alnus, which is not found in the postglacial period before Zone VI, and Carpinus, which is not found before Zone VII. The presence of Alnus and Carpinus, together with such a high Pinus value, the latter presumably indicating relatively cool conditions, is itself puzzling (as is the absence of Betula), and suggests that the assemblage is a mixed one derived from different sources.

It is unlikely that such a floral assemblage could have existed at 33,000 years B.P. without being represented in the existing plant record of Britain or the Netherlands, especially as such a varied flora would require time to build up and decline. Neither would maritime conditions in west Wales account for such thermophilous trees at this 
time. The position of this organic material in kamiform deposits precludes a postglacial age and the most likely explanation is that some elements date from a relatively warm interstadial period, older than the Mid-Würm (i.e. older than about 43,000 years B.P.), or from an earlier interglacial.

Thus, if one assumes with John that the dated material and the pollen are of similar age, the above reassessment would suggest that the $\mathrm{C}^{14}$ activity which implies a date of 33,000 years B.P. is the result of contamination of infinitely old carbon (in $\mathrm{C}^{\mathbf{1 4}}$ terms) by relatively younger carbon. This could have taken place in two ways:-

(a) By percolation of humic acids down from surface. As little as 2 per cent of modern carbon, introduced in this way to infinitely old carbon would give a date of 32,500 years B.P. (Shotton, 1967).

(b) The organic layer at Cil-maenllwyd has clearly been derived, being composed of clasts of wood and rolled organic nodules. If it were deposited in its present position during the retreat stage of the main Würm glaciation (of about 20,000 years B.P.), as is implied by John, there is still a considerable period of time between this date and the time when the component plants were growing. During this interval the material may have lain about at surface, or been deposited and redeposited in a fluvial system, etc., giving considerable opportunities for contamination by younger humus or mixing with younger organic debris.

How do these possibilities affect the interpretation of the $\mathbf{C}^{14}$ date? If $(a)$ has occurred, all the organic material could be of any age pre-dating about 43,000 years B.P. If $(b)$ has occurred, some part of the organic material must pre-date 43,000 years B.P. (that represented by the thermophilous pollen), whilst some must post-date 33,000 years B.P. but pre-date the ice advance whose retreat gave rise to the Banc-y-Warren sands.

Another possibility not suggested by John is that the pollen and the bulk of the dated material are of different ages. However, it is inevitable that some material of similar age to the pollen (which on the basis of the interpretation suggested here is probably infinite in $\mathbf{C}^{14}$ terms) will have been dated, and thus the date will be a measure of this in addition to material younger than 33,000 years B.P.

The above possibilities stem from the premise that John's $\mathbf{C}^{\mathbf{1 4}}$ date and his pollen analysis are in conflict, and I would suggest that there is not sufficient data to select one of these possibilities as the most likely. Thus $\mathrm{C}^{14}$ dates on material such as this are of little value unless accompanied by rigorous analysis of the dated material.

John's pollen analysis is not evidence for a Mid-Würm interstadial; the validity of the $\mathrm{C}^{14}$ date is questionable, and not necessarily improved by the existence of two similar dates from the same bed, which could be similarly contaminated. Neither must the fact that John's interpretation of his data fits the hypothesis, now in vogue, of a main Würm glaciation of west Wales be taken as evidence for the validity of his interpretation.

\section{REFERENCES}

Brown, M. J. F., Ellis-Gruffydd, I. D., Foster, H. D. \& Unwin, D. J. 1967. A new radiocarbon date for Wales. Nature, Lond., 213, 1220-1.

Hammen, T. Van der, MaAlveld, G. C., Vogel, J. C. \& Zagwijn, W. H. 1967. Stratigraphy, climatic succession and radiocarbon dating of the Last Glacial in the Netherlands. Geologie Mijnb., 46, 79-95.

JoHN, B. S. 1967. Further evidence for a Middle Würm Interstadial and a Main Würm Glaciation of south-west Wales. Geol. Mag., 104, 630-3.

Shorton, F. W. 1967. The problems and contributions of methods of absolute dating within the Pleistocene period. Q. Jl geol. Soc. Lond., 122, 357-383.

DEPARTMENT OF GEOLOGY,

UNIVERSITY OF BIRMINGHAM,

G. S. Boulton.

BIRMINGHAM 15.

1st March, 1968. 